Anna Romanik

Biatystok

\title{
Anglicyzmy w rosyjskim dyskursie motoryzacyjnym
}

Słowa kluczowe: dyskurs prasowy, język rosyjski, leksyka motoryzacyjna, anglicyzmy, grafoderywaty

\section{Wstęp}

Rynek prasowy współczesnej Rosji zapewnia swoim czytelnikom ogromny wybór czasopism specjalistycznych, przeznaczonych przede wszystkim dla środowisk ludzi połączonych wspólnymi pasjami. Wśród bogatej oferty prasy branżowej istotne miejsce przypada periodykom motoryzacyjnym, które zawierają opisy innowacyjnych modeli samochodowych, relacjonują wyścigi, rajdy, targi i testy samochodowe, a także przekazują aktualne wieści z rynku paliw. Wzrastający z roku na rok nakład tych czasopism świadczy o ich poczytności i tym samym o popularności nie tylko wśród zawodowych kierowców, mechaników i dealerów samochodowych, ale również amatorów motoryzacji, śledzących najnowsze trendy w przemyśle.

Czasopisma, komentujące aktualne wydarzenia ze świata motoryzacji, są doskonałym medium rejestrującym język, jakim posługują się współcześni Rosjanie w zakresie danej dziedziny życia. Z punktu widzenia językoznawcy, badającego tendencje rozwojowe współczesnych języków narodowych, prasa stanowi istotne źródło faktograficzne.

Obiektem badań niniejszej publikacji są anglicyzmy funkcjonujące w rosyjskim dyskursie motoryzacyjnym. Materiał egzemplifikacyjny został wyekscerpowany z rosyjskiej prasy branżowej poświęconej motoryzacji ( „АвтоЗвук”, „Автоцентр”, „За рулём”, „Офф-роуд драйв”, „Тюнинг авто- 
мобилей"), wydanej w latach 2013-2014. Celem artykułu jest wskazanie powodów intensywnego transferu anglicyzmów do nomenklatury motoryzacyjnej, dokonanie klasyfikacji tematycznej zgromadzonych zapożyczeń, a także zaakcentowanie wybranych problemów związanych z procesami asymilacyjnymi nowego słownictwa w systemie języka rosyjskiego.

\section{Przyczyny importu anglicyzmów z zakresu motoryzacji}

Pozycja języka angielskiego w dzisiejszym świecie jest wyjątkowa, ponieważ jest to język, którego status na przełomie ostatnich lat wzrósł do rangi internacjonalnego, to też określanie go „współczesną łaciną” lub „lingua franca" jest całkowicie uzasadnione. Powody przenikania obcojęzycznych pożyczek do języków biorców zostały już niejednokrotnie zdefiniowane przez wielu lingwistów. Zarówno polscy badacze języka (G. Lisowska, K. Luciński, E. Mańczak-Wohlfeld, K. Wojan), jak i rosyjscy językoznawcy (W. M. Aristowa, M. A. Brejter, L. Ferm, L. Krysin) ${ }^{1}$ zgodnie wskazują na lingwistyczne oraz ekstra-lingwistyczne przyczyny transferu leksykalnego.

Zjawisko importu angielskich pożyczek z zakresu motoryzacji szczególnie nabrało tempa w ostatnim dziesięcioleciu. Po okresie gruntownych przemian ustrojowych przed Rosją pojawiły się nowe perspektywy kontaktów z Zachodem. Światowy rynek motoryzacyjny stał się otwarty również dla Rosjan. Warto zaznaczyć, że wiele koncernów samochodowych skupia się w krajach wysokorozwiniętych, np. w Stanach Zjednoczonych, dlatego też większość literatury motoryzacyjnej oraz dokumentacja techniczna jest redagowana w języku angielskim. Ujednolicenie terminologii samochodowej, wynikające równocześnie z internacjonalnego statusu języka angielskiego, indukuje monizm językowy w przemyśle motoryzacyjnym, co w konsekwencji ułatwia komunikację wielu narodom i tym samym sprzyja dynamicznemu rozwojowi światowego rynku. Kazimierz Luciński [2012, s. 96] podkreśla, że mówiąc wspólnym językiem różne społeczności (np. naukowe) demonstrują swoją przynależność do jednego kręgu zawodowego, w którym język nie stanowi większej przeszkody w kontaktach.

Poza tym, istotna pozycja anglicyzmów w rosyjskiej leksyce samochodowej wynika z przyczyn językowych. Nie sposób nie zauważyć tendencji liberalizacji współczesnego języka rosyjskiego, która jest charakterystyczna

1 Pełne dane bibliograficzne przywołanych autorów znajdują się w spisie bibliografii na końcu pracy. 
również dla innych języków narodowych. Analizując język czasopism motoryzacyjnych, jak również innych magazynów na rosyjskim rynku prasowym, ma się nieodparte wrażenie, że zjawisko demokratyzacji językowej przybiera wręcz formę leseferyzmu [Leseferyzm, zob. Markowski 2005, s. 138-139]. Oznacza to, że język jest samoregulującym się mechanizmem, który używa form odpowiadających aktualnym potrzebom użytkowników i w związku z tym rozwój systemu językowego ma charakter spontaniczny i niekontrolowany. Czytając artykuły zamieszczone w badanych periodykach ma się wrażenie, że autorzy teksów niekiedy celowo nadużywają obcobrzmiących wyrazów, które nadają swoistą ekspresję wypowiedzi, co ma na celu przyciągnięcie uwagi potencjalnego czytelnika.

Leksyka motoryzacyjna powiększa się o nowe jednostki leksykalne w bardzo szybkim tempie, co, między innymi, jest wynikiem potrzeb nominacyjnych w świecie innowacji technologicznych. Autorzy artykułów na łamach analizowanych czasopism niejednokrotnie komentuja pojawienie się neologizmów w prasowej przestrzeni językowej i wyjaśniają czytelnikom ich znaczenie. W jednym z numerów miesięcznika „За рулём” (11. 2011, s. 16) w rozdziale relacjonującym innowacyjne technologie dziennikarz wyjaśnia, co oznacza użyty przez niego wyraz инфотеймент: „По-английски это звучит короче: словечко «инфотеймент» (information + entertainment) стало уже вполне офичиальньм термином. Устройства, которье информируют и развлекают нас, набирают все больший вес, занимают главенствующее место в быту. И в автомобиле тоже". Z dalszej lektury artykułu wynika, że инфотеймент to system funkcji informacyjno-rozrywkowych w samochodzie - udogodnienia w postaci wszelkich mediów i wygód zapewniających luksus, komfort i rozrywkę. W kolejnych numerach miesięcznika uczestnicy dyskursu posługują się tym neologizmem swobodnie, tzn. dany wyraz pojawia się w różnych tekstach bez cudzysłowu, co świadczy o jego asymilacji w leksyce motoryzacyjnej.

W składzie badanych zapożyczeń dominują terminy motoryzacyjne, których pojawienie się w języku rosyjskim jest całkowicie uzasadnione. Natomiast frekwencyjnie rzadsze są anglicyzmy, które przeniknęły do języka na skutek mody językowej. O jej znaczeniu pisze, między innymi, W. Kostomarow [1999]. Za przykład może posłużyć słowo кap. W języku rosyjskim posiada już ono ustabilizowane wieloletnią obecnością odpowiedniki автомобиль сzу машина. Niemniej jednak angielski wariant, nomen omen zarejestrowany $\mathrm{w}$ takim znaczeniu tylko na łamach prasy, często odnotowuje się w tekstach czasopism, co wydaje się niekiedy nawet pewnym nadużyciem ze względu na fakt istnienia w rodzimym zasobie leksykalnym kil- 
ku adekwatnych nominacji. Również leksemy takie jak драйв, трафик, рейд mają swoje rosyjskie odpowiedniki (езда, пробка, пробег/гонки), mimo to $\mathrm{w}$ analizowanych artykułach używane są częściej niż ich rodzime ekwiwalenty.

Badając przyczyny intensywnego transferu anglojęzycznej leksyki w dyskursie prasowym, nie sposób nie zauważyć, że stosowanie obcobrzmiącego słownictwa niejednokrotnie jest zabiegiem intencjonalnym, mającym niekiedy nawet znamiona manipulacji. Autorzy artykułów publikowanych w czasopismach, w szczególności promujących innowacje technologiczne, mają świadomość „działania” angielsko brzmiących pożyczek, które zazwyczaj w odbiorze czytelnika są pozytywnie zabarwione, wywołują określone konotacje, intrygują i przyciągają uwagę. W konsekwencji implikują one pewne zachowania odbiorców tekstów, głównie budząc chęć przetestowania, posiadania obiektów, o których jest mowa w czasopiśmie. Jak podkreślał niejednokrotnie L. P. Krysin [1968, 1997], użycie słownictwa anglojęzycznego w tekstach rosyjskich powoduje zwiększenie poczucia prestiżu socjalnego zarówno wydawcy, jak i czytelnika. Natomiast sam fakt nadawania wypowiedzi charakteru prestiżowego jest efektem manipulowania świadomością ludzi sięgających po prasę motoryzacyjną.

\section{Klasyfikacja leksykalno-semantyczna zapożyczeń}

Analizowane anglicyzmy tworzą zróżnicowany pod względem stylistycznym zbiór jednostek leksykalnych, reprezentowanych zarówno przez wąsko specjalistyczne terminy z zakresu technologii motoryzacyjnej, jak i przez określenia potoczne, czy też żargonizmy.

Zdecydowana większość zgromadzonych anglicyzmów to rzeczowniki, spośród których można wyodrębnić następujące grupy semantyczne:

- rodzaje pojazdów, np. бac (ang. bus), бuг $\boldsymbol{\phi y \boldsymbol { m }}$ (ang. bigfoot), джиn (ang. Jeep), драгстер (ang. dragster), гиперкар (ang. hypercar), poдcmep (ang. roadster), cпидстер (ang. speedster), скрепер (ang. scraper), скутер (ang. scooter), суперкар (ang. supercar), трак (ang. truck), тумблер (ang. tumbler), тюнинг-кар (ang. tuning car), фанни-кар (ang. funny car), хотрод (ang. Hot Rod), шоу-кар (ang. show car);

- typ nadwozia samochodu, np. бизнес-седан (ang. business sedan), брогам (ang. brougham), лифтбек (ang. liftback), минивэн (ang. minivan), пикаn (ang. pick up), спортседан (ang. sport sedan), xардтоп (ang. hardtop), хэибе(э)к (ang. hatchback); 
- części samochodowe oraz funkcje samochodowe, będące atrybutem wyposażenia samochodu, np. акселератор (ang. accelerator), бампер (ang. bumper), интеркулер (ang. intercooler), интерфейс (ang. interface), кик даун (ang. kickdown), климат-контроль (ang. climate control), компаунд (ang. coumpound), пропеллер (ang. propeller), pесивер (ang. receiver), сайлентблок (ang. silent block), селектор (ang. selector), сплиттер (ang. splitter), спойлер (ang. spoiler), стартер (ang. starter), стенд (ang. stand), трап (ang. trap), тюнер (ang. tuner), фаркоn (ang. farkop);

- zawody sportowe (określenia rajdów) - oф $\boldsymbol{\phi}$-роуд драйв (ang. off-road drive), рейд (ang. ride), wyścigi - дор-сламмер (ang. Door Slammer), драг-рейсинг (ang. Drag racing), дрифтинг (ang. drifting), стритрейсинг (ang. street racing), фрирайд (ang. freeride), trasy sportowe - dystanse - квотер (ang. quarter), triki samochodowe - $\boldsymbol{\partial p \boldsymbol { u } \boldsymbol { \phi } \boldsymbol { m }}$ (ang. drift), мотофристайл (ang. freestyle motocross), testy samocho-

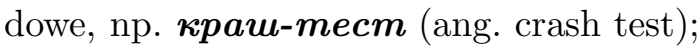

- osoby związane ze światem motoryzacji, np: дизайнер (ang. designer), дилер (ang. dealer), драйвер (ang. driver), стритрейсер (ang. street racer), байкер (иа) (ang. biker), райдер (ang. rider), стритрей$\boldsymbol{c e p}$ (ang. street racer);

- określenia abstrakcyjne odnoszące się do świata motoryzacji, np. $\boldsymbol{\partial u}$ зайн-линия (ang. design + line), драйв (ang. drive), мотор-иоу (ang. motor show), тюнине (ang. tune), эконом-класс (ang. economy class), mpaфuк (ang. traffic).

Silną pozycję w zbiorze zgromadzonych pożyczek zajmują abrewiatury. Są to przede wszystkim określenia systemów oraz funkcji samochodowych, np. $\boldsymbol{A} \boldsymbol{B} \boldsymbol{S}$ (Anti-Lock Braking System), $\boldsymbol{A} \boldsymbol{S R}$ (Acceleration Slip Regulation), $\boldsymbol{E B D}$ (Electronic Brakeforce Distribution), $\boldsymbol{E S P}$ (Electronic Stability Program), DSR (Dynamic Steering Response), GPS (Global Positioning System), DSG (Direct Shift Gearbox) itd. Przytoczone przykłady abrewiatur w zapisie łacińskim posiadają status internacjonalizmów. Skrótowce, zrozumiałe dla wielu narodów, zajmuja szczególne miejsce w leksykonie motoryzacyjnym, gdyż ułatwiają one odczyt parametrów samochodu. Niektóre skrótowce stanowią składową wyrazów złożonych pisanych przez

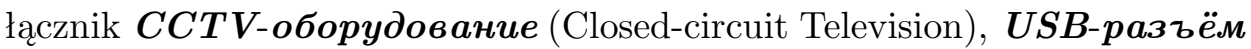
(Universal Serial Bus).

Zapożyczenia angielskie w czasopismach motoryzacyjnych nie są reprezentowane jedynie przez rzeczowniki. Frekwencyjnie rzadziej odnotowuje się przymiotniki, które ze względów formalnych w procesie asymilacji podlegają znacznie bardziej widocznym zmianom, co wynika ze specyfiki morfologii 
języka rosyjskiego. W badanej grupie przymiotników znajdują się jednostki uniwersalne, charakteryzujące się szeroką łączliwością z różnorodnymi pod względem semantycznym wyrazami, na przykład: экстраординарный (ang. extraordinary), эксклюзив (ang. exclusive) ${ }^{2}$, рестайлинговый (ang. restyling), драйверский (ang. driver), тюниговый (ang. tune).

Inne przymiotniki wchodzą w skład terminów w postaci związków wyrazowych, np. компактный лифтбек (ang. compact liftback), джи-эмовский двигатель (ang. GM engine), сенсорный монитор (ang. sensor monitor). Ciekawy przypadek stanowi nominacja swap-нуты $\breve{u ̈}^{3}$ (swap-нутый двигатель), reprezentująca specyficzną i raczej nietypową formę przymiotnika, który zaadaptował się w języku rosyjskim w postaci hybrydy łączącej zapis łaciński oraz cyrylicę (rdzeń - zapisany łacinką, sufiks oraz fleksja - cyrylica). W dyskursie prasowym coraz częściej obserwuje się obecność grafoderywatów [E. Słobodian 2010], jednak głównie formę taką przybierają w procesie asymilacji importowane z języków obcych wyżej wspominane rzeczowniki złożone.

Przytoczone przykłady przymiotników przedostały się na grunt języka rosyjskiego jako składowy element półkalek strukturalnych, będących terminologicznymi określeniami różnych przedmiotów i zjawisk ze świata motoryzacji i szeroko rozumianej technologii.

Peryferyjne miejsce w badanym zbiorze nazw zajmują czasowniki, które są reprezentowane jedynie przez trzy jednostki hybrydalne (дрифтить, лифтовать, тюнить). Użycie przytoczonych egzemplifikacji ogranicza się do wąskiego grona uczestników dyskursu, ze względu na ich żargonową przynależność.

\section{Wybrane zagadnienia asymilacyjne}

Zapożyczenia z zakresu motoryzacji stanowią zbiór zróżnicowanych pod względem stopnia asymilacji jednostek nominacyjnych. W związku z obszernym wachlarzem zagadnień, jakie wiążą się z procesami adaptacyjnymi, w niniejszym artykule zaakcentowano jedynie wybrane kwestie.

2 Wyraz эксклюзив $\mathrm{w}$ zależności od kontekstu w rosyjskich tekstach prasowych występuje zarówno jako przymiotnik, a także jako rzeczownik.

3 Zapożyczony rdzeń swap w języku angielskim oznacza 'przektadnie silnika, stosowana w stabych samochodach $w$ celu ich ulepszenia', zatem hybryda swap-нymbiu, w odniesieniu do silnika, tłumaczy się jako „podrasowany”, czyli ulepszony, silniejszy. 
Z przeglądu powyższych egzemplifikacji wynika, że większość importowanych wyrazów przedostaje się na grunt języka rosyjskiego w postaci pożyczek właściwych, rzadziej asymilują się jako kalki strukturalne i semantyczne. Natomiast istotną pozycję zajmują wtręty językowe (cytaty obcojęzyczne) w zapisie łacińskim, które bardzo chętnie są używane przez autorów artykułów oraz twórców reklam zamieszczanych na łamach czasopism. Na przykład w czasopiśmie „Тюнинг автомобилей” teksty autorskie oraz reklamy wręcz „nafaszerowane” są tego typu pożyczkami (машина делает wheelie на стране; New look получается спортивно-бравый; для души установили мызыку класса hi-end; itd.). Wtręty językowe, czyli wyrazy zachowujące autentyczną, oryginalną pisownię słowa-prototypu, w tekstach rosyjskich są szczególnie widoczne ze względu na kontrast dwóch odrębnych alfabetów. Jak podkreśla B. Nowowiejski [1996, s. 42], wtręty językowe są najwidoczniejszym i najbardziej powierzchownym przejawem ingerencji języka obcego w system języka zapożyczającego. Cytaty łacińskie na tle zapisu cyrylicznego zdecydowanie wyodrębniają się i skupiają na sobie wzrok czytelnika, co sugeruje, że ich pojawienie się w tekście jest zabiegiem celowym, uatrakcyjniającym tekst. Poza tym, ich obecność w tekstach prasowych może także świadczyć o intensywnym przejmowaniu przez język rosyjski obcego słownictwa i ich niedawnym pojawieniu się w nowym systemie, ponieważ formę wtrętów często mają pożyczki na wstępnym etapie procesu importu nowej leksyki.

W kontekście badanych zapożyczeń komentarza wymaga również problematyka adaptacji semantycznej na gruncie języka rosyjskiego. Istotne miejsce w zbiorze analizowanego słownictwa przypada anglicyzmom, które podczas asymilacji w systemie języka rosyjskiego podlegają przeobrażeniom semantycznym, tj. w ich obrębie dochodzi do zwężenia bądź rozszerzenia znaczenia. Są to jednostki posiadające znaczenie ogólne w języku rosyjskim, niemniej wskazują na jakąś szczególną cechę nazwy. Zjawisko to ilustruje leksem байкер, który w wolnym tłumaczeniu oznacza po prostu motocyklistę. Jednak dana pożyczka w świecie motoryzacji ma zdecydowanie węższe znaczenie. Określenie байкер [online] lub jego sfeminizowana wersja байкерша nazywa motocyklistów, których w przeciwieństwie do zwykłych amatorów motocykli wyróżnia jednoznacznie określona filozofia życia. Należą oni do subkultury zainspirowanej ruchem amerykańskich motocyklistów. W Rosji pojawiła się ona w latach 80-tych, a jej członkowie pierwotnie byli określani jako rockerzy. Na początku XXI wieku nowa nazwa баŭкep zastąpiła starą i odnosi się do grupy ludzi zrzeszonych w społeczności, których łączy przede wszystkim motocykl - choper, swoisty wygląd rockmena, a także oryginalne symbole (flaga konfederacji, wyrażająca nonkonformizm człon- 
ków, wizerunek czaszki, emblemat klubu, tatuaże, żelazny krzyż, skórzana kurtka itd.).

Innym jaskrawym przykładem pożyczek, które ilustrują zmiany semantyczne zachodzące w języku-biorcy jest wyraz драйвер. W ogólnym języku rosyjskim funkcjonuje on jako obcojęzyczne określenie popularnego programu komputerowego. Natomiast na łamach badanej prasy specjalistycznej w nomenklaturze motoryzacyjnej, odnotowuje się inne znaczenie przytoczonej nominacji, a mianowicie oznacza ona zawodowego kierowcę. Co ciekawe, wyraz драйвер $\mathrm{w}$ takim znaczeniu nie został zarejestrowany $\mathrm{w}$ Internecie, co może świadczyć o jego ograniczeniach wynikających z przynależności do wąskiej odmiany języka środowiskowego, potocznego, a nawet żargonowego. Zarejestrowanie tej jednostki wyrazowej tylko w dyskursie prasowym jest pewnego rodzaju ewenementem, bo przecież powszechnie wiadomo, że „to co w Internecie, zaraz będzie w gazecie i odwrotnie".

\section{Podsumowanie}

Konkludując, pożyczki angielskie z zakresu motoryzacji, funkcjonujące $\mathrm{w}$ dyskursie prasowym jako element komunikacji masowej, nie tylko są nośnikiem informacji, ale również odzwierciedlają socjalną i pragmatyczną pozycję autora i wydawcy. Zapożyczenia, używane w celu nazwania nowych przedmiotów i zjawisk, wypełniają różnorodne funkcje, między innymi, informacyjną, emotywną oraz perswazyjną (manipulacyjną). Ich obecność na łamach czasopism jest wynikiem zaspokojenia stricte nominacyjnych potrzeb, jak również wynikiem mody językowej, czy też efektem ogólnej tendencji demokratyzacji języka. Stereotypowe przeświadczenie uczestników dyskursu o tym, że wszystko, co pochodzi z "Zachodu” jest lepsze, bardziej prestiżowe ma swoje odzwierciedlenie w języku. Badane anglicyzmy w sposób zróżnicowany poddają się procesowi asymilacji w języku rosyjskim. Niektóre nominacje po adaptacji morfologicznej wykazują dużą aktywność słowotwórczą, inne funkcjonują w tekstach jako wtręty językowe.

\section{Literatura}

Luciński K., Своеобразие современного прочесса языковых заимствований, „Studia Rusycystyczne Uniwersytetu Jana Kochanowskiego” 2012, t. 20, s. 96.

Luciński K ., 2009, Языковые заимствования и ментальность, Kielce. 
Luciński K., 2000, Anglicyzmy w języku polskim i rosyjskim, Kielce.

Markowski A., Kultura języka polskiego. Teoria. Zagadnienia leksykalne, Warszawa 2005, s. 138-139.

Mańczak-Wohlfeld E., 1995, Tendencje rozwojowe wspótczesnych zapożyczeń angielskich w języku polskim, Kraków.

Nowowiejski B., Zapożyczenia leksykalne z języka niemieckiego w polszczyźnie XIX wieku, Białystok 1996, s. 42.

Słobodian E., 2010, Graficzne przyswajanie zapożyczeń z języka angielskiego w języku rosyjskim poczatku XXI wieku i moda jezykowa, ,Linguistica Copernicana" 2 (4)/2010, s. 311-322.

Wojan K. 2010, Przypadkowe i nieprzypadkowe wędrówki leksemów, Gdańsk.

Аристова В. М., 1978, Англо-русские язьюковье контакты, Ленинград.

Брейтер М. А., 1997, Англииизмь в русском языле: история и перспективы: Пособие для иностранных студентов-русистов, Владивосток, с. 34-45.

Костомаров В., 1999, Языковой вкус эпохи. Из наблюдений над речевой практикой масс-медиа, Москва.

Крысин Л. П., 1997, Заимствование иноязьчной лексики, [w:] Najnowsze dzieje języków słowiańskich. Русский языю, red. E. Szirajew, Opole, s. 107-161.

Крысин Л. П., 1968, Иноязычные слова в современном русском языке, Москва. Байкер (в:) «Википедия» [20.09.2014]

\title{
ENGLISH LOANWORDS IN RUSSIAN AUTOMOTIVE PRESS DISCOURSE
}

\author{
S U M M A R Y
}

The main purpose of the article is to analyze the Anglicism, excerpted from Russian automotive magazines. The researched magazines contain news on the automobile industry, the description of modern models of the cars with specifications and prices, etc.

The author of the paper describes English loanwords from different levels. The main aims of the article are: to give thematic classification of excerpted lexemes, to indicate the reasons of lexical transfer from English into Russian and to point out main issues of loanword adaptation.

Anna Romanik e-mail: aniaromanik8@wp.pl 